If there is no information on the distribution of probable error, a position line of any shape simply divides the Earth's surface into two domains and the position is as likely to be in one as in the other. We may arbitrarily denominate them the + domain and the - domain. The three position lines in Fig. I divide the surface of the Earth into seven zones. We follow the convention that the triangle itself is the $3+$ zone; every zone bounded by a side of the triangle is thus a $2+, 1-$ zone and each zone at a vertex of the triangle is a $1+, 2-$ zone.

The 3 - zone is conspicuous by its absence. If the true position were in the minus zone of each and every position line as they have severally been labelled, the cocked hat would necessarily be shaped as in Fig. 2 and the position would be within it. The fact that the cocked hat has taken the form of Fig. 1 and not that of Fig. 2 tells us that, by our convention, the position is in the + domain of at least one position line. Given that we are in the + domain of one position line $(p)$, and may equally be in either the + domain or the - domain of two other position lines $(q, r)$, the four possibilities are shown in Fig. 3 , but we have no idea which position lines correspond to $p, q, r$. Out of four, there is one chance that the position is in the $3+$ zone, two chances that it is in a $2+, 1-$ zone, one chance that it is in a $1+, 2$ - zone and no chance that it is in a 3 -zone. The probability of being in each zone is shown in Fig. 4.

KEY WORDS

I. Errors. 2. Statistics.

\title{
Seamen's Accidental Deaths and Injuries Worldwide: A Methodology and Some Estimates
}

\author{
R. O. Goss, C. Nicholls and S. J. Pettit \\ (University of Wales College of Cardiff)
}

I. INTRODUCTION. For many years Lloyd's Register of Shipping has published data on those deaths of seamen (and ships' passengers) reported to the Corporation of Lloyds as having occurred in total losses of ships. Apart from any under-reporting and errors that may have occurred (probably minimal), there is no coverage of other accidental deaths of seamen (for example, when their ships do not become total losses), and none of injuries. Lloyd's Register do, however, produce complete data on ship losses. The UK Department of Transport also produces full data of accidental deaths and injuries to seamen on UK-registered ships, as well as of the losses of ships in the relevant fleet. Both of these sources are regarded as thoroughly reliable. The ship loss data has been widely, if tacitly, used as a proxy for human casualties.

This brief paper uses these sources (see Table I) to estimate seamen's accidental deaths and injuries worldwide and presents the preliminary results for discussion. Proposals are made to improve the results shown.

Accordingly, section 2 describes the methods used, section 3 presents the results using them and a final section draws conclusions and makes some suggestions for improving the estimates. Table 1 displays the raw data and sources employed. 


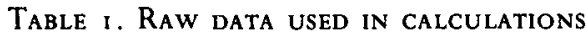

\begin{tabular}{|c|c|c|c|c|c|}
\hline Year & $\begin{array}{l}\text { Worldwide } \\
\text { total } \\
\text { losses of } \\
\text { ships } \\
\text { (g.t. })^{1}\end{array}$ & $\begin{array}{l}\text { UK total } \\
\text { losses of } \\
\text { ships } \\
\text { (g.t. })^{2}\end{array}$ & $\begin{array}{c}\text { UK } \\
\text { seamen's } \\
\text { accidental } \\
\text { deaths }^{2}\end{array}$ & $\begin{array}{c}\text { UK } \\
\text { seamen's } \\
\text { accidental } \\
\text { injuries }^{2}\end{array}$ & $\begin{array}{l}\text { Lloyd's } \\
\text { Register } \\
\text { deaths }\end{array}$ \\
\hline 1979 & 2210259 & 6431 & 60 & $-^{3}$ & 823 \\
\hline 1980 & 1804027 & 94850 & 84 & $-^{3}$ & 622 \\
\hline $198 \mathrm{I}$ & 1238250 & 5986 & 48 & $-^{3}$ & 1215 \\
\hline 1982 & 1631930 & 1883 & $5^{2}$ & $-^{3}$ & 673 \\
\hline 1983 & 1472611 & 6855 & 20 & 1224 & 671 \\
\hline 1984 & 2353941 & 1576 & 18 & 1090 & 525 \\
\hline 1985 & 1651210 & 2370 & 7 & 983 & 619 \\
\hline 1986 & 2608735 & 2836 & 15 & 783 & 1067 \\
\hline 1987 & I 28416 I & 8997 & 47 & 655 & 3841 \\
\hline 1988 & 864670 & 3499 & 13 & 614 & 763 \\
\hline
\end{tabular}

1 Source: Lloyd's Register of Shipping, Statistical Tables. London, annual.

2 Source: HMSO for Department of Transport, Casualties to vessels and accidents to men. London, annual.

${ }^{3}$ Data not available for these years.

4 Source: Lloyd's Register of Shipping, Casualty Return. London, annual.

2. METHODS

(a) Deaths. There is no reason to believe that either the death rates per 1000 employed or per rooo g.t. in the UK fleet are typical of the world fleet. However, there seems no reason why the number of deaths per 1000 g.t. lost should differ between the UK and world fleets. We have, therefore, calculated the rate of seamen's deaths per 1000 g.t. in the UK fleet, and the total loss rate of UK-registered ships for 1000 g.t. on the UK register, both from the DTp publication. ${ }^{\prime}$ DTp does not refer to 'total losses' (which is an insurance term) but their listing of individual ships allows this to be verified. For example, for 1988 , total deaths for crew members were 13 and the UK-registered fleet was 5875000 g.t. so the seamen's accidental death rate was:

$$
0.0022 \text { I } 3 \text { per } 1000 \text { g.t. }
$$

Within the same fleet, 3499 g.t. was lost in that year giving a loss rate per 1000 g.t. of 0.5956 .

Lloyd 's Register publish extensive data on ship losses, ${ }^{2}$ showing the world figures for gross tonnage of ships totally lost in the fleet. We thus calculate the world loss rate of ships per 1000 g.t. in the fleet. For example, the 1988 figures are 864670 g.t. totally lost out of a world fleet of 403406079 g.t., giving a loss rate per 1000 g.t. of $2 \cdot 1434$, or about $3^{.6}$ times the rate of the UK fleet. We then gross up the death rate by the differences in loss rates.

Thus, for 1988 we have

$$
\frac{2 \cdot 1434 \times 0.002213}{0.5956}=0.007964
$$

which is the seamen's accidental death rate per 1000 g.t. for the world. Multiplying 
this by the 1000 g.t. in the world fleet gives us an estimate of the number of seamen's accidental deaths in the world fleet. 1988 figures give us:

$$
0.007964 \times 403406079=3213 .
$$

The general formula then, is :

$$
\mathrm{W}_{\mathrm{d}}=\frac{\mathrm{L}_{\mathrm{wg}}}{\mathrm{W}_{\mathrm{g}}} \times \frac{\mathrm{UK}_{\mathrm{d}}}{\mathrm{UK}_{\mathrm{g}}} \times \frac{\mathrm{UK}_{\mathrm{g}}}{\mathrm{L}_{\mathrm{ukg}}} \times \mathrm{W}_{\mathrm{g}},
$$

where $\mathrm{W}_{\mathrm{d}}=$ worldwide seamen's accidental deaths; $\mathrm{L}_{\mathrm{wg}}=$ worldwide total losses of ships in gross tonnes; $\mathrm{W}_{\mathrm{g}}=$ world fleet in gross tonnes; $\mathrm{UK}_{\mathrm{d}}=\mathrm{UK}$ seamen's accidental deaths; $\mathrm{UK}_{\mathrm{g}}=U \mathrm{UK}$ fleet in gross tonnes; $\mathrm{L}_{\mathrm{ukg}}=\mathrm{UK}$ total losses of ships in gross tunnes.

However, expressed in this way it is clear that $\mathrm{W}_{\mathrm{g}}$ and $\mathrm{UK}_{\mathrm{g}}$ each appears twice and cancels, leaving:

$$
\mathrm{W}_{\mathrm{d}}=\frac{\mathrm{L}_{\mathrm{wg}} \times \mathrm{UK}_{\mathrm{d}}}{\mathrm{L}_{\mathrm{ukg}}} .
$$

Substituting for 1988 , we have

$$
\frac{864670 \times 13}{3499}=3213 .
$$

(b) Injuries. Equally, there seems no reason to expect the ratio of deaths to injuries to differ much between the UK and world fleet. For 1988 , this ratio is 47.23 , being obtained by dividing the 614 number of injured people by the 13 deaths. The number of seamen injured in accidents on UK ships may then be divided by the number of deaths on UK ships and grossed up by the number of deaths for the world. For 1988 the figures are :

$$
\frac{614}{13} \times 3213=15175^{2}
$$

The general formula then, is :

$$
W_{i}=\frac{U K_{1}}{U K_{d}} \times W_{d}
$$

where $W_{1}=$ worldwide seamen's accidental injuries; $U_{1}=U K$ seamen's accidental injuries; $U_{d}=U K$ seamen's accidental deaths; $W_{d}=$ worldwide seamen's accidental deaths.

3. RESULTS. Table 2 shows the results of making the above calculations, for worldwide deaths $\left(W_{d}\right)$ for the ro years $1979-88$ inclusive, and compares them with Lloyd's Register figures for deaths in total losses over the same period. In addition, Table 3 shows the results of making the above calculations for worldwide injuries $\left(W_{1}\right)$ for the 6 years $1983^{-8}$ inclusive, together with the corresponding figures for worldwide deaths and Lloyd's Register figures for deaths in total losses over the same period. A shortening of the time period is necessary because figures for accidental injuries to UK seamen $\left(\mathrm{UK}_{\mathrm{i}}\right)$ are not available before 1983 .

Since the margin of error inherent in the methods described above may vary from year to year, results are also shown for the 10-year and 6-year totals and averages.

Table 2 shows an estimate totalling 135545 deaths over the 10 years (1979-88) with an average rate of 13555 deaths per year. The ratio of estimated deaths to those published by Lloyd's Register varies from 66.96 in 1982 to 1.75 in 1988 . These, and 
TABle 2. Estimates of SEAmen's ACcidental DEATHS, worldWide (1979-88)

\begin{tabular}{cccc}
\hline Year & Seamen's deaths & $\begin{array}{c}\text { Lloyd's Register } \\
\text { deaths }\end{array}$ & $\begin{array}{c}\text { Rates of estimated } \\
\text { deaths to Lloyd's } \\
\text { Register data }\end{array}$ \\
\hline 1979 & 20621 & 823 & 25.06 \\
1980 & 1598 & 662 & 2.41 \\
1981 & 9929 & 1215 & 8.17 \\
1982 & 45067 & 673 & 66.96 \\
1983 & 4296 & 671 & 6.40 \\
1984 & 26885 & 525 & $51 \cdot 21$ \\
1985 & 3430 & 619 & 5.54 \\
1986 & 13798 & 1067 & 12.93 \\
1987 & 6708 & 3841 & 1.75 \\
1988 & 3213 & 763 & 4.21 \\
Total & 135545 & 10888 & 12.45 \\
10-year average & 13555 & 1089 & 12.45 \\
\hline
\end{tabular}

other, annual variations are not surprising, for reasons discussed in the next section. The average ratio over the 10 years is 12.45 .

Table 3 shows an estimate totalling $333^{8}$ I $_{3}$ injuries over the six years $\left(1983^{-8}\right)$ with an average rate of $55635^{2}$ injuries per year. Correspondingly, over the same period, estimated total deaths equal $5^{8} 330$ with an average of 9722 deaths per year, whilst the ratio of estimated deaths to those published by Lloyd's Register averages 779.

4. CONClusions, discussion and proposals for improvement. The absolute numbers of seamen accidentally killed on British ships are quite small - figures used in this study range from 7 to 84 . This must, therefore, induce substantial and variable margins of error into these calculations. This is why stress has been laid on the average annual figures: not on those for any single year. Again, Lloyd's Register figures (which include passengers) for 1987 appear to include over 3000 lost in the 'Dona Paz', an inter-island passenger ferry in the Philippines. (Spouge, ${ }^{3}$ however, gives 4400 deaths for that disaster.)

It would probably be possible to improve this by extending the calculations back, say

Table 3. Estimates of Seamen's accidental, injuries, and deaths, worldwide (1983-8)

\begin{tabular}{crccc}
\hline Year & $\begin{array}{c}\text { Seamen's } \\
\text { accidental } \\
\text { injuries }\end{array}$ & $\begin{array}{c}\text { Seamen's } \\
\text { deaths }\end{array}$ & $\begin{array}{c}\text { Lloyd's Register } \\
\text { deaths }\end{array}$ & $\begin{array}{c}\text { Ratio of estimated } \\
\text { deaths to Lloyd's } \\
\text { Register data }\end{array}$ \\
\hline 1983 & 262915 & 4296 & 671 & 6.4 \\
1984 & 1628036 & 26885 & 525 & $51 \cdot 209$ \\
1985 & 481670 & 3430 & 619 & 5.541 \\
1986 & 720256 & 13798 & 1067 & 12.931 \\
1987 & 93484 & 6708 & 3841 & 1.746 \\
1988 & 151752 & 3213 & 763 & 4.211 \\
Total & 3338113 & 58330 & 7486 & 779 \\
6-year average & 556352 & 9722 & 1248 & 779 \\
\hline
\end{tabular}


for 15 years : but it would be much better if a wider sample were used, for example by including other fleets besides that of the UK - provided that comparable statistical bases could be established. A first step in this might be to identify, possibly through IMO, the number of countries whose statistics could be used for such purposes.

It should, therefore, be stressed that the methods suggested in this paper are intended for discussion and improvement. They are not intended as criticisms of any statistical authority and it is hoped that constructive criticism will lead to their improvement.

\title{
REFEREN CES
}

1 HMSO for Dept. of Transport. Casualties to Vessels and Accidents to Men. London, annual.

2 Casualty Return. Lloyd's Register of Shipping: London, annual for total losses. Statistical Tables. London, annual, for size of world fleet.

${ }^{3}$ Spouge, J. R. (1990). Passenger ferry safety in the Philippines. RINA Spring Meeting. The Naval Architect forthcoming.

KEY WORDS

1. Statistics. 2. Safety.

\section{'Position Fixing in a Fast Moving Ship by Culmination of a Celestial Body'}

\author{
from James N. Wilson
}

A recent paper on this subject by Ranta', in common with many others, ignores a fundamental method by which the time of meridian transit can be exactly calculated relative to the time of maximum altitude. The author has used a complicated approach to arrive at an answer which can be very simply computed. He joins countless others in recognizing via computer a phenomenon not widely understood, despite the fact that it is axiomatic. Alas, he also succumbs, albeit with awesome mathematics, to the brute force approach for obtaining a solution.

A paper of my own in $1985^{2}$ describes this exact method. I have since been reminded that a similar derivation was in the Admiralty Manual of Navigation, Volume III, out of print for several decades. The phenomenon referred to above, and described in my paper, is succinctly described in Bowditch's American Practical Navigator, and undoubtedly other publications. Unfortunately, as noted above, the phenomenon is still not widely understood. More articles by author Ranta et al. must help in alerting navigators that vessel motion, even at sailboat speeds and moderate latitudes, affects calculation of the time of meridian passage rclative to the time of maximum altitude. Author Ranta's reference to the 'Classical Method' could have mentioned Bowditch's note to the effect that it is for a stationary observer with no change in declination. As noted in my paper, with observations of the Moon, being stationary is insignificant, due to the often large hourly changes in declination.

Author Ranta's curve fitting of a very sparse set of observations is crucial. Alas, he bases some extremely precise calculations on an insignificant amount of data, considering 